\title{
Correction to: Combining multicriteria decision analysis and cost-benefit analysis in the assessment of maritime projects financed by the European Investment Bank
}

\author{
Mark Clintworth $^{1} \cdot$ Evangelos Boulougouris $^{2} \cdot$ Byung Suk Lee $^{2}$
}

(C) Macmillan Publishers Ltd., part of Springer Nature 2018

Correction to: Marit Econ Logist (2018) 20:29-4

https://doi.org/10.1057/s41278-017-0072-x

An acknowledgement was omitted from this article: The views expressed in this paper represent those of the authors and not necessarily those of any of their affiliations.

The authors apologise for their error.

The original article can be found online at https://doi.org/10.1057/s41278-017-0072-x.

Mark Clintworth

mbc@eib.org

1 European Investment Bank, Boulevard Konrad Adenauer, L2950 Luxembourg, Luxembourg

2 Department of Ocean Architecture and Marine Engineering, University of Strathclyde, Glasgow, UK 